\title{
Effect of Nutrient Solution Concentration at the Heading Time on the Growth, Development, and Seed Storage Protein Content of Rice Plants in a Controlled Environment
}

\author{
Shinichi Maruyama, Yasuhiro Ishigami and Eiji Goto \\ Graduate School of Horticulture, Chiba University, Matsudo, Chiba 271-8510, Japan
}

(Received February 3, 2010)

\begin{abstract}
Genetically modified (GM) rice varieties that store up pharmaceutical proteins in seeds have recently been developed. Since the pharmaceutical protein-encoding genes of these varieties are connected with the promoter of seed storage protein-encoding genes, the pharmaceutical protein content increases as the seed protein content increases. Rice varieties were grown in hydroponic culture at different nutrient solution concentrations at the heading time in a controlled environment. Emergence of non-productive stems was inhibited through an early reduction in the nutrient solution concentration due to accelerated translocation from the leaf blade, leaf sheath, and stem to the seed. Further, the seed storage protein composition was altered by regulating the concentration of the nutrient solution. When the nutrient solution concentration was increased just before heading occurred, translocation to the seeds as well as the generation of non-productive stems decreased. The total protein concentration of rice seeds was not increased by the treatments of nutrient solution concentration, however, it was greater in the plants grown in the present study than in plants grown in field cultivation. Seeds in which high concentrations of total protein and seed storage protein accumulate can be produced when the nutritional content is kept constant in hydroponic culture.
\end{abstract}

Keywords: artificial light, closed plant production system, glutelin, hydroponic culture, prolamin

\section{INTRODUCTION}

Genetically modified (GM) crops that store up pharmaceutical proteins that are not original components in edible parts have been recently developed using transgenic technology (Fischer et al., 2004). Antibodies and vaccines are produced in the plant body and used as pharmaceutical compounds (Ma et al., 2003). Compared with earlier methods of using animal cells and microscopic organisms, plants allow for cost-effective production of pharmaceutical proteins while eliminating risks of product contamination with human pathogens.

GM rice varieties that produce the cholera toxin vaccine (Nochi et al., 2007) and pollenosis allergen (Takagi and Takaiwa, 2008) in seeds have been developed. Pharmaceutical proteinencoding genes of these GM rice varieties are connected with the promoter of a seed storage protein-encoding gene that is especially expressed in albumen. Therefore, the pharmaceutical protein content increases as seed protein content increases. Such pharmaceutical proteins must be produced in high concentrations and should be stable. These goals can be achieved through complete

Corresponding author: Eiji Goto, fax: $+81-47-308-8841$, e-mail : goto@faculty.chiba-u.jp 


\section{S. MARUYAMA ET AL.}

environmental control by using a closed plant production system that can be isolated perfectly from the outer environment. However, neither an environmental condition nor a cultivation method that is suitable for cultivation of GM rice has been clarified since there are few commercial cultivation results and recent studies of rice in a closed plant production system.

Hydroponic culture is suitable for cultivation of GM crops in a closed plant production system since it is easy to control both the underground environment and the media disposal process. In order to produce a large amount of pharmaceutical proteins, it is necessary to clarify the environmental conditions that increase total protein and seed storage protein content in seeds since pharmaceutical protein content increases as seed protein content increases. In hydroponic cultures of rice in experimental studies, nutrient solution concentration was gradually lowered after heading occurred to stimulate translocation from the leaf blade, leaf sheath, and stem to the seed (Mae, 1993). Therefore, the nitrogen content of the raw material of protein in the seeds decreased. In field cultivation of rice, it has been reported that the total protein content of seeds increases by additional fertilization at the heading time (Honjo, 1971) and that total protein and seed storage protein content of the seeds increases by the use of additional nitrogen fertilization at or after full heading time (Taira, 1970; Tamaki et al., 1989). In hydroponic rice cultures, total protein and seed storage protein content of seeds are expected to increase as the concentration of the nutrient solution increased at the heading time as well as with additional fertilization in field cultivation. On the other hand, it has been reported that ripening rate and yield are decreased by use of additional nitrogen fertilization 10 or 20 days after heading (Kumagai et al., 1994), and the nitrogen accumulated in rice seed at harvesting time consists of $10-30 \%$ nitrogen absorbed and assimilated after heading and $70-90 \%$ nitrogen that was translocated from existing vegetative organs (Mae and Ohira, 1981). Therefore, yield and total protein content are not expected to increase when nutrient solution concentration is increased 10 days after heading, but nutrient solution concentration from just before heading to just after heading is important.

In order to clarify the ideal environmental conditions needed to produce large amounts of pharmaceutical proteins in a closed plant production system, the present study investigated the following: the effects of time-controlling the start of nutrient solution concentration reduction on the growth, development and seed storage protein content of rice plants (experiment 1); and the effects of changing the nutrient solution concentration just before heading on the growth, development and seed storage protein content of rice plants (experiment 2).

\section{MATERIALS AND METHODS}

The closed plant production system used for the experiments consisted of a rice nursery room and a rice production room located on the grounds of the faculty of horticulture at Chiba University. The rice nursery room and rice production room have floor areas of $4 \mathrm{~m}^{2}$ and $15 \mathrm{~m}^{2}$, respectively, and use ceramic metal halide lamps (M400FCEH-W/BUD/H0, Iwasaki Electric) as light sources. Light intensity, air temperature, relative humidity, and $\mathrm{CO}_{2}$ concentration are precisely controlled in each room.

Non-GM rice (Oryza sativa L., Nipponbare) plants were used for material plants. If GM rice plants are grown under environmental conditions in which seed storage protein content of non-GM rice plants increases, pharmaceutical protein content of GM rice plant is expected to increase with increasing seed storage protein content. After the rice seeds were sterilized for $24 \mathrm{~h}$, they were germinated for $24 \mathrm{~h}$ in an incubator in which the air temperature was set at $30^{\circ} \mathrm{C}$. The germinated seeds were grown by deep flow technique in the rice nursery room (light period: $16 \mathrm{~h} \mathrm{~d}^{-1}$, air temperature: $23^{\circ} \mathrm{C}$, photosynthetic photon flux (PPF): $600 \mu \mathrm{mol} \mathrm{m}^{-2} \mathrm{~s}^{-1}, \mathrm{CO}_{2}$ concentration: $600 \mu \mathrm{mol}$ $\mathrm{mol}^{-1}$ ) until 28 days after sowing (DAS). At that point, they were transplanted to the rice production room (light period: $12 \mathrm{~h} \mathrm{~d}^{-1}$, air temperature: $27^{\circ} \mathrm{C} / 23^{\circ} \mathrm{C}$ [light/dark], PPF: $1,000 \mu \mathrm{mol} \mathrm{m}^{-2} \mathrm{~s}^{-1}$, 
$\mathrm{CO}_{2}$ concentration: $400 \mu \mathrm{mol} \mathrm{mol}{ }^{-1}$, planting density: $120 \mathrm{plant} / \mathrm{m}^{2}$ ) and rice plants that were 7 days before heading until 77 DAS were used in the experiments. Since the boot stage begins about 6 days before heading (Hoshikawa, 1975), rice plants on the beginning day of boot stage were defined as rice plants 7 days before heading.

The nutrient solution composition and management schedule of nutrient solution concentration used were according to Mae (1993) (Table 1). The nutrient solution was tap water adjusted to $\mathrm{pH}$ 5.0-5.5 for $0^{-13} \mathrm{DAS}$, and was $1 / 4$ times the standard concentration adjusted to $\mathrm{pH} 5.0^{-5.5} 14$ DAS. After that point, the nutrient solution was $1 / 2$ and $3 / 4$ times the standard concentration every 7 days, and was the standard concentration for 35-77 DAS. The nutrient solution was added twice every 7 days. Since the nitrogen constituent in the nutrient solution had been decreased 50 DAS, $42.0 \mathrm{mg} / \mathrm{L} \mathrm{NH} \mathrm{NH}_{3}$ was added to the nutrient solution.

Treatments in experiment 1 included Cont. (existing experiment cultivation method), NE (time of start of nutrient solution concentration reduction was 7 days earlier than Cont.), and NL (7 days after Cont.) (Table 2). Treatments in experiment 2 included N1, in which the nutrient solution concentration at 10 days from 7 days before heading was the standard concentration, and N3, in which the nutrient solution concentration at 10 days from 7 days before heading was 3 times the standard concentration (Table 3). In both experiments 1 and 2, rice plants were grown for 54 days under environmental conditions similar to material cultivation.

When the experiments ended, 16 and 24 rice plants were gathered from experiments 1 and 2 for measurement of the number of stems, number of ears, dry weight, leaf area, and number of seeds.

Brown rice was broken up with a multi-beads shocker (Yasui Kikai Ltd.) at 2,500 ppm for 15

Table 1 Composition of the standard nutrient solution for hydroponic culture of rice plant used in the experiments.

\begin{tabular}{ccc}
\hline Element & Chemical compound & Element concentration $(\mathrm{mg} / \mathrm{L})$ \\
\hline $\mathrm{N}$ & $\mathrm{NH}_{4} \mathrm{NO}_{3}$ & 42.0 \\
$\mathrm{P}$ & $\mathrm{NaH}_{2} \mathrm{PO}_{4} \cdot 2 \mathrm{H}_{2} \mathrm{O}$ & 27.9 \\
$\mathrm{~K}, \mathrm{~S}$ & $\mathrm{~K}_{2} \mathrm{SO}_{4}$ & $35.1,24.8$ \\
$\mathrm{Ca}$ & $\mathrm{CaCl}_{2} \cdot 2 \mathrm{H}_{2} \mathrm{O}$ & 18.0 \\
$\mathrm{Mg}$ & $\mathrm{MgCl}_{2} \cdot 6 \mathrm{H}_{2} \mathrm{O}$ & 22.2 \\
$\mathrm{Fe}$ & $\mathrm{Fe}-\mathrm{EDTA}$ & 3.8 \\
\hline
\end{tabular}

Table 2 Treatments of nutrient solution concentration at the heading time (experiment 1).

\begin{tabular}{lccccc}
\hline & \multicolumn{5}{c}{ Nutrient solution concentration } \\
\cline { 2 - 6 } & Before & $-7^{--}-1 \mathrm{~d}^{*}$ & $0-6 \mathrm{~d}$ & $7-13 \mathrm{~d}$ & $14-20 \mathrm{~d}$ \\
\hline Cont. & & 1.00 & 0.50 & 0.25 & 0.00 \\
NE & 1.00 & 0.50 & 0.25 & 0.00 & 0.00 \\
NL & & 1.00 & 1.00 & 0.50 & 0.25 \\
\hline
\end{tabular}

* Number of days after heading. In NE and NL treatments starting points for reducing nutrient solution concentration were respectively 7 days earlier and 7 days later than that of Cont. Nutrient solutions was tap water after day 21 .

Table 3 Treatments of nutrient solution concentration at the heading time (experiment 2).

\begin{tabular}{cccccc}
\hline & \multicolumn{5}{c}{ Nutrient solution concentration } \\
\cline { 2 - 6 } & Before & $-7--2 \mathrm{~d}^{*}$ & $3-9 \mathrm{~d}$ & $10^{-16 \mathrm{~d}}$ & $17-46 \mathrm{~d}$ \\
\hline N1 & 1.00 & 3.00 & 0.50 & 0.25 & 0.00 \\
N3 & 1.00 & 3 &
\end{tabular}

* Number of days after heading. In N1 and N3 treatments nutrient solution concentrations at 10 days from 7 days before heading were respectively the standard concentration and 3 times the standard concentration. 


\section{S. MARUYAMA ET AL.}

s. Total proteins were extracted with extraction buffer (4\% SDS, $8 \mathrm{M}$ urea, $5 \%$ mercaptoethanol, $20 \%$ glycerin, $50 \mathrm{mM}$ Tris- $\mathrm{HCl}[\mathrm{pH} 6.8]$ ) at $30^{\circ} \mathrm{C}$ for $4 \mathrm{~h}$. The solution was centrifuged at 21,880 $\times \mathrm{g}$ for $5 \mathrm{~min}$ and the supernatant solution was used for protein analysis. Total protein content of the protein extraction solution was measured with an RCDC protein assay kit (Bio-Rad laboratories). Each seed storage protein was separated by SDS-PAGE using an electrophoresis system (Phast System, GE Healthcare). The main seed store protein was measured with image analysis software (Doc-It Software, Funakoshi Ltd.), and the ratio of each protein content was calculated. The possibility of variation of total protein and seed storage protein concentration of each stem existed due to nutrient solution processing for a short time in experiment 2. In experiment 2, ripe seed dry weight and a total protein and seed protein concentration of first, third, and fifth stem of order of heading were individually measured.

\section{RESULTS AND DISCUSSION}

Experiment 1: Effects of time-controlling the start of nutrient solution concentration reduction on the growth, development and seed storage protein content of rice plants

The number of stems of plants grown in NE was lower than that of plants grown with the other treatments (Table 4). However, the number of ears did not differ among treatments and the rate of fruitful stems of plants grown in Cont., NE, and NL were 62.7, 82.7, and 58.8\%, respectively. Ripe seed, leaf blade, and other parts making up the dry weights of plants grown in NE tended to be smaller than those of plants grown in other treatments. It is conceivable that although emergence of non-productive stems was inhibited by early nutrient solution concentration reduction because of acceleration of translocation from the leaf blade, leaf sheath, and stem to the seeds, the amount of photosynthesis until harvesting decreased. Brown rice dry weight, number of ripe seeds, and percentage of ripe seeds did not differ among treatments (Table 5). It was inferred that although the amount of photosynthesis until harvesting of plants grown in NE decreased, an amount of translocation of plants grown in NE was similar to those of plants grown in other treatments.

Total protein concentration of seeds did not differ among treatments (Table 6). The 22-23 $\mathrm{kDa}$ glutelin ratio did not differ among treatments, however, the 37-39 $\mathrm{kDa}$ glutelin ratio of plants grown in NE was lower than those of plants grown in the other treatments, and the $10^{-16} \mathrm{kDa}$

Table 4 Effects of nutrient solution condition at the heading time on the growth of rice plants.

\begin{tabular}{lccccc}
\hline & $\begin{array}{c}\text { Number of } \\
\text { stems per plant }\end{array}$ & $\begin{array}{c}\text { Number of } \\
\text { ears per plant }\end{array}$ & $\begin{array}{c}\text { Ripe seed } \\
\text { dry weight }(\mathrm{g})\end{array}$ & $\begin{array}{c}\text { Leaf blade } \\
\text { dry weight }(\mathrm{g})\end{array}$ & $\begin{array}{c}\text { Other parts } \\
\text { dry weight }(\mathrm{g})\end{array}$ \\
\hline Cont. & $20.1 \mathrm{a}$ & $12.6 \mathrm{a}$ & $9.0 \mathrm{a}$ & $3.8 \mathrm{~b}$ & $20.4 \mathrm{a}$ \\
NE & $13.3 \mathrm{~b}$ & $11.0 \mathrm{a}$ & $8.5 \mathrm{a}$ & $3.5 \mathrm{~b}$ & $17.9 \mathrm{a}$ \\
NL & $19.4 \mathrm{a}$ & $11.4 \mathrm{a}$ & $10.5 \mathrm{a}$ & $5.4 \mathrm{a}$ & $20.8 \mathrm{a}$ \\
\hline
\end{tabular}

In NE and NL treatments starting points for reducing nutrient solution concentration were respectively 7 days earlier and 7 days later than that of Cont. Different letters indicate treatments that were significantly different based on Tukey's test $(P<0.05) ; \mathrm{n}=16$.

Table 5 Effects of nutrient solution condition at the heading time on brown rice dry weight and the number of seeds of rice plants.

\begin{tabular}{lcccc}
\hline & $\begin{array}{c}\text { One brown rice } \\
\text { dry weight }(\mathrm{mg})\end{array}$ & $\begin{array}{c}\text { Number of total } \\
\text { seeds per plant }\end{array}$ & $\begin{array}{c}\text { Number of ripe } \\
\text { seeds per plant }\end{array}$ & $\begin{array}{c}\text { Percentage of } \\
\text { ripe seeds }(\%)\end{array}$ \\
\hline Cont. & $19.0 \mathrm{a}$ & $751 \mathrm{a}$ & $407 \mathrm{a}$ & $55.9 \mathrm{a}$ \\
NE & $19.7 \mathrm{a}$ & $666 \mathrm{a}$ & $360 \mathrm{a}$ & $56.5 \mathrm{a}$ \\
NL & $19.8 \mathrm{a}$ & $731 \mathrm{a}$ & $460 \mathrm{a}$ & $62.3 \mathrm{a}$ \\
\hline
\end{tabular}

In NE and NL treatments starting points for reducing nutrient solution concentration were respectively 7 days earlier and 7 days later than that of Cont. Different letters indicate treatments that were significantly different based on Tukey's test $(P<0.05) ; \mathrm{n}=16$. 
prolamin ratio of plants grown in NE was greater than those of plants grown in the other treatments. It has been reported that although glutelin begins to accumulate in seeds at early ripening, prolamin begins to accumulate later, and the amount of nitrogen in the nutrient solution influences glutelin content at the first stage of ripening and prolamin content at late stage of ripening ( $\mathrm{Li}$ and Okita, 1993). It is conceivable that the $37-39 \mathrm{kDa}$ glutelin ratio of plants grown in $\mathrm{NE}$ was lower than those of plants grown in the other treatments because the nutrient solution concentration of $\mathrm{NE}$ at the first stage of ripening was lower than that of other treatments. In contrast, the $10^{-}-16 \mathrm{kDa}$ prolamin ratio of plants grown in $\mathrm{NE}$ was lower than those of plants grown in the other treatments despite the fact that the nutrient solution concentration of NE at the late stage was lower than of the other treatments. Since the number of tillers generated after heading of plants grown in Cont. and NL was greater than that generated after heading of plants grown in NE and the photosynthates of plants grown in Cont. and NL were used for the emergence and development of new tillers, the possibility exists that translocation from the leaf blade, leaf sheath, and stem to the seeds of plants grown in Cont. and NL decreased.

These findings demonstrate that emergence of non-productive stems was inhibited by early start of nutrient solution concentration reduction due to acceleration of translocation from the leaf blade, leaf sheath and stem to the seeds, and that the composition of seed storage protein was changed via regulation of nutrient solution concentration.

Experiment 2: Effects of nutrient solution concentration just before heading on the growth, development and seed storage protein content of rice plants

The number of stems of plants grown in N3 was greater than that of plants grown in N1. However, the number of ears did not differ between treatments, and the rate of fruitful stems of plants grown in N1 and N3 were $90.9 \%$ and $78.0 \%$, respectively (Table 7). Since the number of ears of plants grown in both treatments was similar to that of plants at the start of the experiment, new tillers of plant grown in N1 increased little after the start of the experiment, and although new tillers of plants grown in N3 were increased, those went on to become non-productive stems. Ripe seeds, leaf blades, and other parts comprising dry weight were no different between treatments.

Table 6 Effects of nutrient solution condition at the heading time on total protein concentration and seed storage protein ratio of rice plants.

\begin{tabular}{lcccc}
\hline & $\begin{array}{c}\text { Total protein } \\
\text { concentration }(\%)\end{array}$ & $\begin{array}{c}37-39 \mathrm{kDa} \\
\text { glutelin ratio* }\end{array}$ & $\begin{array}{c}22-23 \mathrm{kDa} \\
\text { glutelin ratio* }\end{array}$ & $\begin{array}{c}10-16 \mathrm{kDa} \\
\text { prolamin ratio* }\end{array}$ \\
\hline Cont. & $8.5 \mathrm{a}$ & $0.39 \mathrm{a}$ & $0.34 \mathrm{a}$ & $0.27 \mathrm{~b}$ \\
$\mathrm{NE}$ & $8.5 \mathrm{a}$ & $0.36 \mathrm{~b}$ & $0.34 \mathrm{a}$ & $0.30 \mathrm{a}$ \\
$\mathrm{NL}$ & $8.5 \mathrm{a}$ & $0.37 \mathrm{ab}$ & $0.35 \mathrm{a}$ & $0.28 \mathrm{ab}$ \\
\hline
\end{tabular}

* The ratio of each content to total seed storage protein content. In NE and NL treatments starting points for reducing nutrient solution concentration were respectively 7 days earlier and 7 days later than that of Cont. Different letters indicate treatments that were significantly different based on Tukey's test $(P<0.05) ; \mathrm{n}=16$.

Table 7 Effect of nutrient solution concentration at the heading time on the growth of rice plants.

\begin{tabular}{lcccccc}
\hline & $\begin{array}{c}\text { Number of } \\
\text { stems per plant }\end{array}$ & $\begin{array}{c}\text { Number of } \\
\text { ears per plant }\end{array}$ & $\begin{array}{c}\text { Ripe seed } \\
\text { dry weight }(\mathrm{g})\end{array}$ & $\begin{array}{c}\text { Leaf blade } \\
\text { dry weight }(\mathrm{g})\end{array}$ & $\begin{array}{c}\text { Other parts } \\
\text { dry weight }(\mathrm{g})\end{array}$ & $\begin{array}{c}\text { Leaf area } \\
\left(\mathrm{cm}^{2}\right)\end{array}$ \\
\hline 77 DAS & 7.5 & - & - & 4.3 & 6.4 & 1121 \\
\hline N1 & 7.7 & 7.0 & 7.2 & 3.9 & 16.8 & 966 \\
N3 & 9.1 & 7.1 & 6.8 & 3.9 & 15.8 & 830 \\
& $*$ & ns & ns & ns & ns & $*$ \\
\hline
\end{tabular}

${ }^{2}$ Values at start of the experiment (77 days after sowing).

In $\mathrm{N} 1$ and $\mathrm{N} 3$ treatments nutrient solution concentrations at 10 days from 7 days before heading were respectively the standard concentration and 3 times the standard concentration.

ns and * indicate non-significance and significance at $P<0.05$ by Student's $t$-test, respectively; $\mathrm{n}=24$. 


\section{S. MARUYAMA ET AL.}

Leaf blade dry weight and leaf area of plants grown in both treatments were lower than those of plants at start of the experiment because completely dead leaves were not used for the analysis and leaf blade dry weight and leaf area of increased leaves after the start of the experiment were lower than those of completely dead leaves. Since leaf areas of plants grown in N1 was greater than those of plants grown in $\mathrm{N} 3$ and leaf blade dry weight did not differ between the 2 treatments, leaf thickness of plants grown in $\mathrm{N} 3$ was probably greater than that of plants in N1. It was inferred that because although common rice leaves gradually died due to translocation from leaves to seeds after heading, new tillers of plants grown in N3 were generated after start of the experiment and young leaves existed until the end of the experiment. There was the possibility that leaf area of plants grown in N3 decreased since photosynthates normally accumulating in existing leaf blades were used for emergence of new tillers.

The number of total and ripe seeds per plant did not differ between treatments (Table 8), however, brown rice dry weight and percentage of ripe seeds of plants grown in N1 were greater than those of plants grown in N3. It was inferred that translocation of photosynthates to the seeds of plants grown in N3 was inhibited compared to that of plants grown in N1.

These findings demonstrate that since new tillers were generated by using a highconcentration nutrient solution just before heading, the amount of translocation to seed and percentage of ripe seeds decreased.

Ripe seed dry weight per stem of the first and third stems of order of heading of plants grown in both treatments were comparable, however, ripe seed dry weight per stem of the fifth stem in order of heading was lower than that of the first and third stems in order of heading (Fig. 1A). The percentage of ripe seeds per stems of plants grown in both treatments did not differ among stems (Fig. 1B). Total protein concentration per first and third stem in order of heading of plants grown in both treatments were comparable, however, total protein concentration per stem in the fifth stem in order of heading was lower than those of the first and third stems in order of heading (Fig. 1C). Since tillers generated late was disadvantageous for growth period and nutrition (Hoshikawa, 1975) and translocation to seed was decreased, ripe seed dry weight per stem and total protein concentration of the fifth stem in order of heading was lower than that of the first and third stem in order of heading. It was conceivable that variation among stems was less affected by nutrient solution processing for a short time just before heading.

The prolamin ratio of the first, third, and fifth stems (37-39 kDa glutelin, 22-23 kDa glutelin, and $10-16 \mathrm{kDa}$, respectively) in order of heading did not differ between treatments (Figs. 2A and B). In field cultivation of rice, it has been reported that although the total protein content increases with nitrogen nutrition during the development of the ear, the composition of the seed storage protein does not change greatly (Nishimura et al., 2007). It was inferred that composition of the seed storage protein was unaffected by nutrient solution concentration at the heading time in hydroponic culture as well as in field cultivation. It has been reported that the $37-39 \mathrm{kDa}$ glutelin, $22-23 \mathrm{kDa}$ glutelin, and $10^{-16} \mathrm{kDa}$ prolamin ratios of rice plant seeds (Nihonmasari) grown in field cultivation were $0.39,0.34$, and 0.26 (Ohdaira et al., 2009), respectively, and that those of plants grown

Table 8 Effect of nutrient solution concentration at the heading time on seeds of rice plants.

\begin{tabular}{ccccc}
\hline & $\begin{array}{c}\text { One brown rice } \\
\text { dry weight }(\mathrm{mg})\end{array}$ & $\begin{array}{c}\text { Number of total } \\
\text { seeds per plant }\end{array}$ & $\begin{array}{c}\text { Number of ripe } \\
\text { seeds per plant }\end{array}$ & $\begin{array}{c}\text { Percentage of } \\
\text { ripe seeds }(\%)\end{array}$ \\
\hline N1 & 18.4 & 480 & 339 & 71 \\
N3 & 17.7 & 521 & 330 & 63 \\
& $* *$ & ns & ns & $* *$ \\
\hline
\end{tabular}

In $\mathrm{N} 1$ and $\mathrm{N} 3$ treatments nutrient solution concentrations at 10 days from 7 days before heading were respectively the standard concentration and 3 times the standard concentration. ns and $* *$ indicate non-significance and significance at $P<0.01$ by Student's $t$-test, respectively; $\mathrm{n}=24$. 

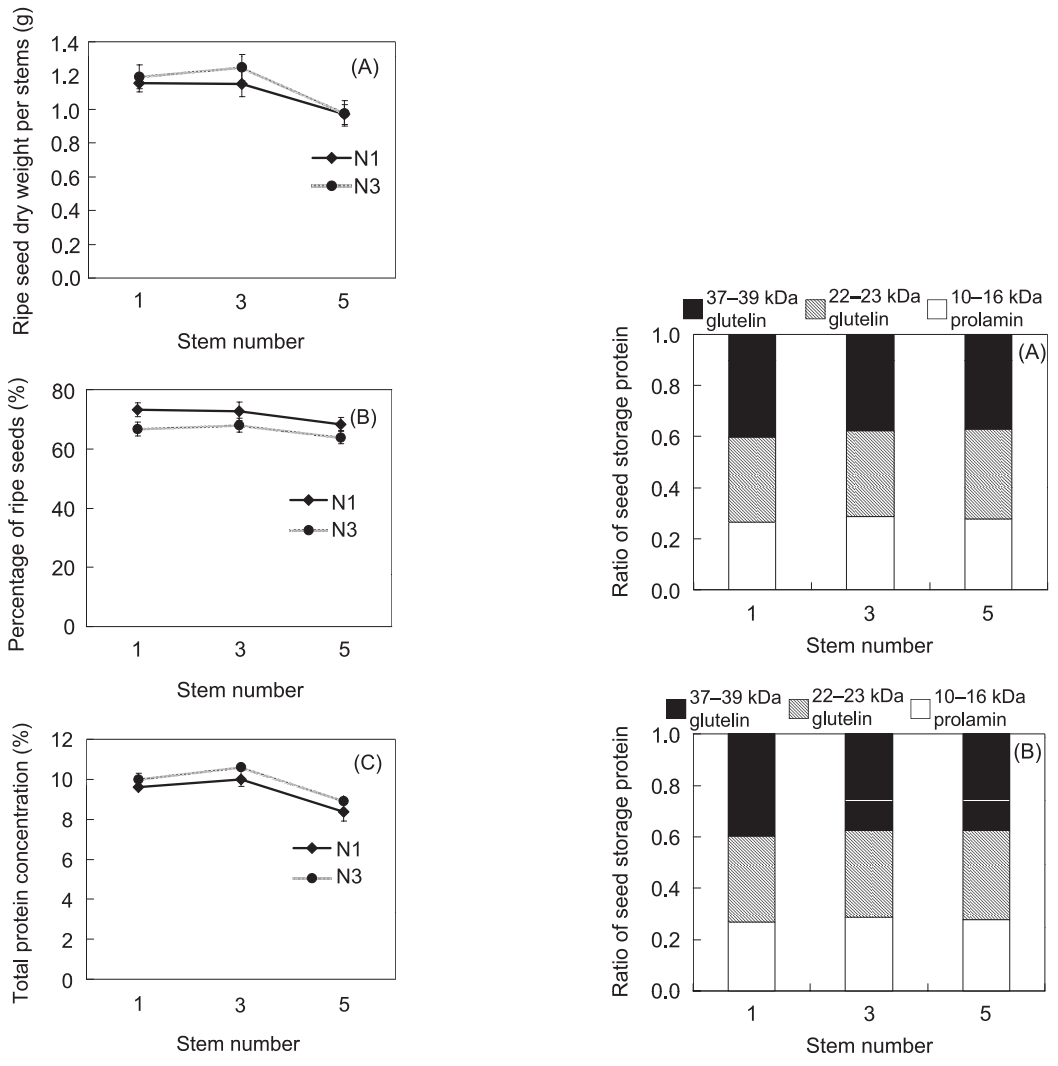

Fig. 1 Effect of nutrient solution concentration at the heading time on ripe seed dry weight (A), percentage of ripe seeds (B), and total protein concentration $(\mathrm{C})$ of rice plants. In N1 and N3 treatments nutrient solution concentrations at 10 days from 7 days before heading were respectively the standard concentration and 3 times the standard concentration. Each bar indicates mean $\pm \mathrm{SE}$ of 24 plants.

Fig. 2 Effect of nutrient solution concentration at the heading time on ratio of seed storage protein concentration of rice plants. (A) N1, (B) N3. In N1 and N3 treatments nutrient solution concentrations at 10 days from 7 days before heading were respectively the standard concentration and 3 times the standard concentration.

in N1 were $0.38,0.34$, and 0.27 , respectively. It was inferred that the composition of seed storage proteins in seeds of plants grown in field cultivation was similar to that of plants grown by hydroponic culture.

In conclusion, when nutrient solution concentration was increased just before heading in order to increase total protein and seed storage protein content of rice seed, the amount of translocation to seeds and generation of non-productive stems decreased. The total protein concentration of rice seeds of plants grown in the present study was not increased by the treatments of nutrient solution concentration, however, it was $8.5-9.8 \%$, which was greater than approximately $8.0 \%$ total protein concentration of rice seed of plants grown in field cultivation (Higashi et al., 1974; Imai et al., 1998; Matue et al., 1991). It was inferred that although the amount of nutritional content in soil was changed by fertilization at intervals in field cultivation, since an amount of nutritional content 


\section{S. MARUYAMA ET AL.}

was maintained at all times in hydroponic cultures, seeds in which total protein and seed storage protein is accumulated in high concentration can be produced.

\section{REFERENCES}

Fischer, R., Stoger, E., Schillberg, S., Christou, P., Twyman, R. M. 2004. Plant-based production of biopharmaceuticals. Curr. Opin. Plant Biol. 7: 152-158.

Higashi, T., Kushibuchi, K., Ito, R. 1974. Studies on breeding for high protein rice: I. Protein content of different rice varieties and their relations with some agronomic traits including yield. Jpn. J. Breed. 24: $88^{-}$ 96 (Japanese).

Honjo, K. 1971. Studies on protein content in rice grains. II. Effects of the fertilization on protein content and protein production in paddy grain. Jpn. J. Crop Sci. 40: 190-196 (Japanese).

Hoshikawa, K. 1975. The growing rice plant. No-san-gyoson Bunka Kyokai, Tokyo, pp 317 (Japanese).

Imai, S., Ogata, T., Matue, Y. 1998. Annual and locational variation in physicochemical properties of rice. Jpn. J. Crop Sci. 67: 30-35 (Japanese).

Kumagai, K., Togashi, M., Ueno, M., Tanaka, N. 1994. Yearly and regional variation and effect of topdressing on the protein content of rice. Yamagata Agric. Exp. Stn. 28: 69-80 (Japanese).

Li, X., Okita, T. W. 1993. Accumulation of prolamines and glutelins during rice seed development: A quantitative evaluation. Plant Cell Physiol. 34: 385-390.

Ma, J. K., Drake, P. M., Christou, P. 2003. The production of recombinant pharmaceutical proteins in plant. Nature Reviews Genetics 4: 794-805.

Mae, T. 1993. Laboratory scale culture of rice. Plant Cell Technol. 5: 63-67 (Japanese).

Mae, T., Ohira, K. 1981. The remobilization of nitrogen related to leaf growth and senescence in rice plants (Oryza sativa L.). Plant Cell Physiol. 22: 1067-1074.

Matue, Y., Mizuta, K., Furuno, K., Yoshida, T. 1991. Studies on palatability of rice grown in northern Kyushu. Jpn. J. Crop Sci. 60: 497-503 (Japanese).

Nishimura, M., Miyahara, K., Morita, R. 2007. Influence of application on speed-protein composition and their accumulation pattern during ripening stage in seed protein mutant rice. Jpn. J. Crop Sci. 76: 562-568 (Japanese).

Nochi, T., Takagi, H., Yuki, Y., Yang, L., Masumura, T., Mejima, M., Nakanishi, U., Matsumura, A., Uozumi, A., Hiroi, T., Morita, S., Tanaka, K., Takaiwa, F., Kiyono, H. 2007. Rice-based mucosal vaccine as a global strategy for cold-chain- and needle-free vaccination. Proc. Natl. Acad. Sci. USA. 104: 1098610991.

Ohdaira, Y., Takeda, H., Sasaki, R. 2009. Distribution of seed proteins in rice grain of seed-protein mutant cultivars. Jpn. J. Crop Sci. 78: 58-65 (Japanese).

Taira, H. 1970. Effect of fertilization on protein content in high yield rice. Jpn. J. Crop Sci. 39: 200-203 (Japanese).

Takagi, H., Takaiwa, F. 2008. Development of rice seed-based edible vaccine for cedar pollen allergy. Bio Industry 25: 78-84.

Tamaki, M., Ebata, M., Tashiro, T., Ishikawa, M. 1989. Physico-ecological studies on quality formation of rice kernel. Jpn. J. Crop Sci. 58: 653-658. 